\title{
Phylogenetic placement of Cryptophiale, Cryptophialoidea, Nawawia, Neonawawia gen. nov. and Phialosporostilbe
}

\author{
Yang $\mathrm{J}^{1,2}$, Liu NG ${ }^{1,2,3}$, Liu JK ${ }^{1}$, Hyde KD ${ }^{2,4,5}$, Jones EBG ${ }^{6}$, Liu ZY ${ }^{1}$ \\ ${ }^{1}$ Guizhou Key Laboratory of Agricultural Biotechnology, Guizhou Academy of Agricultural Sciences, Guiyang 550006, \\ Guizhou, China \\ ${ }^{2}$ Center of Excellence in Fungal Research, Mae Fah Luang University, Chiang Rai 57100, Thailand \\ ${ }^{3}$ Faculty of Agriculture, Natural Resources and Envinonment, Naresuan University, Phitsanulok 65000, Thailand \\ ${ }^{4}$ Key Laboratory for Plant Diversity and Biogeography of East Asia, Kunming Institute of Botany, Chinese Academy of \\ Science, Kunming 650201, Yunnan, China \\ ${ }^{5}$ World Agroforestry Centre, East and Central Asia, 132 Lanhei Road, Kunming, 650201, Yunnan, China \\ ${ }^{6}$ Department of Entomology and Plant Pathology, Faculty of Agriculture, Chiang Mai University, Chiang Mai 50200, \\ Thailand
}

Yang J, Liu NG, Liu JK, Hyde KD, Jones EBG, Liu ZY 2018 - Phylogenetic placement of Cryptophiale, Cryptophialoidea, Nawawia, Neonawawia gen. nov. and Phialosporostilbe. Mycosphere 9(6), 1132-1150, Doi 10.5943/mycosphere/9/6/5

\begin{abstract}
During a survey of freshwater fungi in China and Thailand, seven fresh collections representing four species in Chaetosphaeriaceae are described and illustrated based on morphological characters and phylogenetic analyses of combined LSU and ITS sequence data. Cryptophiale udagawae, Cryptophialoidea fasciculata and Nawawia filiformis were re-collected and are reported with the first sequence data. Two collections of Phialosporostilbe from China and Thailand are identified and introduced as a new species named $P$. scutiformis with the first sequence data for the genus. A new genus Neonawawia is introduced to accommodate Ne. malaysiana. New combinations are proposed for the genera Neonawawia and Phialosporostilbe. Descriptions and illustrations of the new taxa and identified species are provided. Reference specimens of Cryptophiale udagawae, Cryptophialoidea fasciculata and Nawawia filiformis are designated in this study. Phylogenetic placements of the genera Cryptophiale, Cryptophialoidea, Nawawia, Neonawawia and Phialosporostilbe are discussed.
\end{abstract}

Key words - 2 new taxa - asexual fungi - Chaetosphaeriaceae - reference specimens Sordariomycetes - taxonomy

\section{Introduction}

The family Chaetosphaeriaceae was introduced by Réblová et al. (1999) to accommodate Chaetosphaeria and its allies. The long history of taxonomic problems of Chaetosphaeria has been reviewed in detail by Réblová et al. (1999) and Réblová (2000). Chaetosphaeria is characterized by superficial, dark globose perithecia, cylindrical asci, hyaline septate ascospores and phialidic dematiaceous asexual morphs. Ten asexual genera (Cacumisporium, Catenularia, Chalara, Chloridum, Cylindrotrichum, Dictyochaeta, Gonytrichum, Menispora, Phialophora and Zanclospora) of dematiaceous hyphomycetes producing phialidic conidia have been linked to Chaetosphaeria (Réblová 2000). Morphological differences between species in Chaetosphaeria are 
often manifested among the asexual morphs, while the morphological characters of the sexual morphs show less variation which is often insufficient for their correct identification (Réblová \& Winka 2000, Liu et al. 2016). Phylogenetic studies showed that Chaetosphaeria is not monophyletic (Réblová \& Winka 2000, Liu et al. 2016, Hyde et al. 2018). Réblová et al. (1999) included seven genera in the family Chaetosphaeriaceae while presently 38 genera are accepted within the family (Lumbsch \& Huhndorf 2010, Maharachchikumbura et al. 2016, Wijayawardene et al. 2018).

In this study, seven fresh collections resulted in the identification of four chaetosphaeriaceous hyphomycetes obtained from freshwater habitats in China and Thailand. A new freshwater species and three previously described species were collected and identified based on phylogenetic analyses and morphological characters. We therefore introduce Phialosporostilbe scutiformis as a novel taxon with an illustrated account and phylogenetic evidence. Molecular sequence data is generated for the first time for the genera Cryptophialoidea and Phialosporostilbe and for the species Cryptophiale udagawae, Cryptophialoidea fasciculata and Nawawia filiformis. Phylogenetic analyses based on a combined LSU and ITS sequence dataset are presented to provide further evidence for the classification of these genera, which have been sequenced, in Chaetosphaeriaceae. A new genus Neonawawia is introduced and new combinations are proposed for the genera Neonawawia and Phialosporostilbe.

\section{Materials and Methods}

\section{Collection and examination of specimens}

Specimens of submerged decaying twigs were collected from streams in Chiang Rai (in June 2017), Krabi (in December 2015), Trat (in April 2017) Provinces, Thailand and Guizhou (in October 2016, August 2017) Province, China. Specimens were brought to the laboratory in plastic bags and incubated in plastic boxes lined with moistened tissue paper at room temperature for one week. A Motic SMZ 168 Series dissecting microscope was used for morphological observation of the fungal structures on natural substrata. The fungal structures were collected and transferred using a syringe needle to a small drop of distilled water on a clean slide and covered with a cover glass. The fungal fruiting bodies and details were examined using a Nikon ECLIPSE 80i compound microscope and photographed with a Canon 600D/70D digital camera fitted to the microscope. Measurements were made with the Tarosoft Image Frame Work program and images used for figures were processed with Adobe Photoshop CS6 software. Single spore isolations were made onto potato dextrose agar (PDA) or water agar (WA) and later transferred onto malt extract agar (MEA) or PDA following the method of Chomnunti et al. (2014). Specimens (dry wood with fungal material) were deposited in the Herbarium of Mae Fah Luang University (MFLU), Chiang Rai, Thailand and Herbarium of Cryptogams, Kunming Institute of Botany, Academia Sinica (HKAS), Kunming, China. Axenic cultures were deposited in Mae Fah Luang University Culture Collection (MFLUCC) and Guizhou Culture Collection (GZCC). Facesoffungi and Index Fungorum numbers are registered as outlined in Jayasiri et al. (2015) and Index Fungorum (2018).

\section{DNA extraction, PCR amplification and sequencing}

Isolates were grown on PDA/MEA medium at $25^{\circ} \mathrm{C}$ for one month. Fungal mycelium was scraped off and transferred to a $1.5 \mathrm{ml}$ microcentrifuge tube using a sterilized lancet for genomic DNA extraction. Ezup Column Fungi Genomic DNA Purification Kit (Sangon Biotech, China) was used to extract DNA following the manufacturer's instructions. LSU and ITS gene regions were amplified using the primer pairs LR0R with LR5 or LR7 (White et al. 1990) and ITS5 or ITS1 with ITS4 (Vilgalys \& Hester 1990). The amplifications were performed in a $25 \mu 1$ reaction volume containing $9.5 \mu \mathrm{ddH}_{2} \mathrm{O}, 12.5 \mu \mathrm{l} 2 \times$ Taq PCR Master Mix with blue dye (Sangon Biotech, China), $1 \mu \mathrm{l}$ of DNA template and $1 \mu \mathrm{l}$ of each primer $(10 \mu \mathrm{M})$. The amplification condition for LSU and ITS consisted of initial denaturation at $94^{\circ} \mathrm{C}$ for $3 \mathrm{~min}$; followed by 40 cycles of $45 \mathrm{~s}$ at $94^{\circ} \mathrm{C}, 50 \mathrm{~s}$ at $56^{\circ} \mathrm{C}$ and $1 \mathrm{~min}$ at $72^{\circ} \mathrm{C}$ and a final extension period of $10 \mathrm{~min}$ at $72^{\circ} \mathrm{C}$. Purification and sequencing 
of PCR products were carried out using the above-mentioned PCR primers at Sangon Biotech (Shanghai) Co. Ltd. in China.

\section{Phylogenetic analyses}

The taxa included in the phylogenetic analyses were selected and obtained from previous studies and GenBank (Réblová \& Winka 2000, Crous et al. 2016, Liu et al. 2016, Ma et al. 2016, Konta et al. 2017, Hyde et al. 2018). LSU and ITS gene regions were used for the combined sequence data analyses. Sequences were optimized manually to allow maximum alignment and maximum sequence similarity. The sequences were aligned using the online multiple alignment program MAFFT v.7 (http://mafft.cbrc.jp/alignment/server/) (Katoh \& Standley 2013). The alignments were checked visually and improved manually where necessary.

Phylogenetic analysis of the sequence data consisted of maximum likelihood (ML) using RAxML-HPC v.8 (Stamatakis 2006, Stamatakis et al. 2008) on the XSEDE Teragrid of the CIPRES science Gateway (https://www.phylo.org) (Miller et al. 2010) with rapid bootstrap analysis, followed by 1000 bootstrap replicates. The final tree was selected among suboptimal trees from each run by comparing likelihood scores under the GTRGAMMA substitution model.

The program MrModeltest v.2.3 (Nylander 2008) was used to infer the appropriate substitution model that would best fit the model of DNA evolution for the combined dataset for Bayesian inference analysis with GTR+G+I substitution model selected. Posterior probabilities (PP) (Rannala \& Yang 1996, Zhaxybayeva \& Gogarten 2002) were determined by Markov Chain Monte Carlo sampling (MCMC) in MrBayes v.3.2 (Ronquist \& Huelsenbeck 2003). Six simultaneous Markov chains were run for 1 million generations, with trees sampled every 100 generations (resulting in 10000 trees). The first 2000 trees, representing the burn-in phase of the analyses were discarded and the remaining 8000 trees were used for calculating posterior probabilities (PP) in the majority rule consensus tree (Larget \& Simon 1999).

The resulting trees were printed with FigTree v. 1.4.3 (http://tree.bio.ed.ac.uk/software/figtree/), and the layout was created in Microsoft Powerpoint for Mac v. 15.19.1. The alignment of phylogenetic analyses and phylogenetic trees were deposited in TreeBASE (www.treebase.org, submission number 23182). Sequences generated in this study were submitted to GenBank (Table 1).

Table 1 Isolates and sequences used in this study (newly generated sequences are indicated in bold with new taxa in red, ex-type strains are indicated with ${ }^{\mathrm{T}}$ after the strain number).

\begin{tabular}{|c|c|c|c|}
\hline \multirow{2}{*}{ Species } & \multirow{2}{*}{ Source } & \multicolumn{2}{|c|}{ GenBank accession no. } \\
\hline & & LSU & ITS \\
\hline Adautomilanezia caesalpiniae & CC-LAMIC $102 / 12^{\mathrm{T}}$ & KU170671 & KX821777 \\
\hline Anacacumisporium appendiculatum & HMAS $245593^{\mathrm{T}}$ & КT001553 & КT001555 \\
\hline Anacacumisporium appendiculatum & HMAS 245602 & KT001554 & KT001556 \\
\hline Brunneodinemasporium brasiliense & CBS $112007^{\mathrm{T}}$ & JQ889288 & JQ889272 \\
\hline Brunneodinemasporium jonesii & GZCC $16-0050^{\mathrm{T}}$ & KY026055 & KY026058 \\
\hline Chaetosphaeria innumera & SMH 2748 & AY017375 & AY906956 \\
\hline Chaetosphaeria pygmaea & MR 1365 & AF178545 & AF178545 \\
\hline Chloridium lignicola & CBS $143.54^{\mathrm{T}}$ & AF178544 & AF178544 \\
\hline Codinaeopsis gonytrichoides & CBS 593.93 & AF178556 & AF178556 \\
\hline Cryptophiale hamulata & MFLUCC 18-0098 & MG386756 & - \\
\hline Cryptophiale udagawae & MFLUCC 18-0422 & MH758211 & MH758198 \\
\hline Cryptophiale udagawae & MFLUCC 18-0428 & MH758210 & MH758197 \\
\hline Cryptophialoidea fasciculata & MFLUCC 17-2119 & MH758208 & MH758195 \\
\hline Dendrophoma cytisporoides & CBS $223.95^{\mathrm{T}}$ & JQ889289 & JQ889273 \\
\hline Dictyochaeta siamensis & MFLUCC $15-0614^{\mathrm{T}}$ & KX609952 & KX609955 \\
\hline
\end{tabular}


Table 1 Continued.

\begin{tabular}{|c|c|c|c|}
\hline \multirow{2}{*}{ Species } & \multirow{2}{*}{ Source } & \multicolumn{2}{|c|}{ GenBank accession no. } \\
\hline & & LSU & ITS \\
\hline Dictyochaeta simplex & CBS 966.69 & AF178559 & AF178559 \\
\hline Dinemasporium decipiens & CBS 592.73 & JQ889291 & JQ889275 \\
\hline Dinemasporium morbidum & CBS $129.66^{\mathrm{T}}$ & JQ889296 & JQ889280 \\
\hline Echinosphaeria canescens & SMH 4791 & AY436403 & - \\
\hline Ellisembia brachypus & HKUCC 10555 & DQ408563 & - \\
\hline Eucalyptostroma eucalypti & CBS $142074=$ CPC $28764^{\mathrm{T}}$ & KY173500 & KY173408 \\
\hline Eucalyptostroma eucalypti & CBS $142075=$ CPC 28748 & KY173499 & KY173407 \\
\hline Exserticlava vasiformis & TAMA 450 & AB753846 & - \\
\hline Helminthosphaeria clavariarum & $\mathrm{SMH} 4609^{\mathrm{T}}$ & AY346283 & - \\
\hline Infundibulomyces cupulata & BCC $11929^{\mathrm{T}}$ & EF113979 & EF113976 \\
\hline Infundibulomyces oblongisporus & $\mathrm{BCC} 13400^{\mathrm{T}}$ & EF113980 & - \\
\hline Lasiosphaeria ovina & SMH 4605 & AY436413 & AY587923 \\
\hline Lecythothecium duriligni & CBS 101317 & AF261071 & - \\
\hline Leptosporella arengae & MFLUCC $15-0330^{\mathrm{T}}$ & MG272246 & MG272255 \\
\hline Leptosporella gregaria & SMH $4290^{\mathrm{T}}$ & AY346290 & - \\
\hline Linocarpon arengae & MFLUCC $15-0331^{\mathrm{T}}$ & MG272247 & - \\
\hline Linocarpon cocois & MFLUCC $15-0812^{\mathrm{T}}$ & MG272248 & - \\
\hline Melanopsammella gonytrichii & SMH 3785 & AF466085 & - \\
\hline Melanopsammella vermicularioides & FC 404 & AF466087 & - \\
\hline Menispora tortuosa & DAOM $231154=$ AFTOL-ID 278 & AY544682 & KT225527 \\
\hline Menispora tortuosa & CBS 214.56 & AF178558 & AF178558 \\
\hline Menisporopsis theobromae & MFLUCC 15-0055 & KX609954 & KX609957 \\
\hline Morrisiella indica & HKUCC 10827 & DQ408578 & - \\
\hline Nawawia filiformis & MFLUCC 16-0853 & MH758206 & - \\
\hline Nawawia filiformis & MFLUCC 17-2394 & MH758209 & MH758196 \\
\hline Neonawawia malaysiana & $\mathrm{CPC} 16757=\mathrm{CBS} 125544^{\mathrm{T}}$ & GU229887 & GU229886 \\
\hline Neopseudolachnella magnispora & MAFF $244359^{\mathrm{T}}$ & AB934042 & AB934066 \\
\hline Neopseudolachnella uniseptata & MAFF $244360^{\mathrm{T}}$ & AB934043 & AB934067 \\
\hline Phialosporostilbe scutiformis & MFLUCC 17-0227 ${ }^{\mathrm{T}}$ & MH758207 & MH758194 \\
\hline Phialosporostilbe scutiformis & MFLUCC 18-1288 & MH758212 & MH758199 \\
\hline Pseudodinemasporium fabiforme & MAFF $244361^{\mathrm{T}}$ & AB934044 & AB934068 \\
\hline Pseudolachnea fraxini & CBS $113701^{\mathrm{T}}$ & JQ889301 & JQ889287 \\
\hline Pseudolachnea hispidula & MAFF 244364 & AB934047 & AB934071 \\
\hline Pseudolachnella asymmetrica & MAFF $244366^{\mathrm{T}}$ & AB934049 & AB934073 \\
\hline Pseudolachnella botulispora & MAFF $244367^{\mathrm{T}}$ & AB934050 & AB934074 \\
\hline Pyrigemmula aurantiaca & CBS $126743^{\mathrm{T}}$ & HM241692 & HM241692 \\
\hline Pyrigemmula aurantiaca & CBS 126744 & HM241693 & HM241693 \\
\hline Rattania setulifera & GUFCC 15501 & HM171322 & GU191794 \\
\hline Ruzenia spermoides & SMH 4606 & AY436422 & - \\
\hline Sporoschisma hemipsilum & SMH 2125 & AY346292 & - \\
\hline Sporoschisma palauense & MFLUCC $15-0616^{\mathrm{T}}$ & KX358075 & KX505870 \\
\hline Stanjehughesia vermiculata & HKUCC 10840 & DQ408570 & - \\
\hline Striatosphaeria codinaeophora & SMH 1524 & AF466088 & - \\
\hline
\end{tabular}


Table 1 Continued.

\begin{tabular}{|c|c|c|c|}
\hline \multirow{2}{*}{ Species } & \multirow{2}{*}{ Source } & \multicolumn{2}{|c|}{ GenBank accession no. } \\
\hline & & LSU & ITS \\
\hline Striatosphaeria codinaeophora & MR 1230 & AF178546 & AF178546 \\
\hline Synaptospora plumbea & SMH3962 & KF765621 & - \\
\hline Tainosphaeria crassiparies & SMH 1934 & AF466089 & - \\
\hline Tainosphaeria siamensis & MFLUCC15-0607 T & KX609953 & KX609956 \\
\hline Thozetella nivea & - & EU825200 & EU825201 \\
\hline Thozetella pinicola & - & EU825195 & EU825197 \\
\hline Umbrinosphaeria caesariata & CBS 102664 & AF261069 & - \\
\hline Zanclospora iberica & FMR $11584=$ CBS $130426^{\mathrm{T}}$ & KY853544 & KY853480 \\
\hline Zanclospora iberica & FMR 12186 & KY853545 & KY853481 \\
\hline Zignoella pulviscula & MUCL 15710 & AF466090 & - \\
\hline Zignoella pulviscula & SMH 3289 & AF466091 & - \\
\hline
\end{tabular}

\section{Phylogenetic results}

Seven isolates of asexual fungi obtained from the incubated specimens of submerged wood were identified in the family Chaetosphaeriaceae. The analyzed dataset consisted of combined LSU (848 bp) and ITS (547 bp) sequence data (a total of 1395 characters including gaps) for 69 taxa in Chaetosphaeriales with Lasiosphaeria ovina (SMH 4605) as the outgroup taxon. The Bayesian tree is shown in Fig. 1.

Genera in Chaetosphaeriaceae sequenced in Réblová \& Winka (2000), Lumbsch \& Huhndorf (2010), Crous et al. (2012), Hashimoto et al. (2015a, b), Liu et al. (2015, 2016), Maharachchikumbura et al. (2015), and the recent sequenced genera Adautomilanezia (Ma et al. 2016), Anacacumisporium (Crous et al. 2016), Cryptophiale (Hyde et al. 2018) and Eucalyptostroma (Crous et al. 2016) were included in our analyses. The analyzed ML and Bayesian trees were similar in topology and did not differ significantly. Of our seven isolates, two were identified as Cryptophiale udagawae (MFLUCC 18-0422 and MFLUCC 18-0428) and clustered together with $C$. hamulata (MFLUCC 18-0098) with good support. Cryptophialoidea fasciculata (MFLUCC 17-2119) clustered close to the genera Cryptophiale, Morrisiella and Stanjehughesia. Two isolates of Nawawia filiformis (MFLUCC 172394 and MFLUCC 16-0853) were close to the genera Exserticlava, Umbrinosphaeria and Zanclospora. Two isolates of Phialosporostilbe scutiformis (MFLUCC 17-0227 and MFLUCC 181288) clustered together and they were well-supported as a sister clade to Menisporopsis theobromae (MFLUCC 15-0055). In addition, Neonawawia malaysiana (CPC 16757) clustered as a sister clade to the family Chaetosphaeriaceae.

\section{Taxonomy}

Cryptophiale udagawae Pirozynski \& Ichinoe, Can. J. Bot. 46(9): 1126 (1968)

Fig. 2

Index Fungorum number: IF329371; Facesoffungi number: FoF04866

Saprobic on decaying plant substrates. Asexual morph: Colonies effuse, hairy, scattered, glistening, with conspicuous branches at the apex of conidiophores and slimy mass of conidia. Mycelium mostly immersed, partially superficial. Conidiophores macronematous, mononematous, solitary, erect, straight or slightly curved, dark brown, smooth, thick-walled, septate below the branches, $(90-) 100-130(-140) \times(4.5-) 5.2-6.5(-7.2) \mu \mathrm{m}(\overline{\mathrm{x}}=115 \times 5.8 \mu \mathrm{m}, \mathrm{n}=20)$, dichotomously branching towards the apex and generally above the fertile region, with 2-3 dichotomous divisions tapering towards the apex; terminal branches 11.5-38 $\times 2.8-4.5 \mu \mathrm{m}$. Fertile region from middle up to the first dichotomy, 37-63 $\times 11-16 \mu \mathrm{m}$, consisting of two rows of phialides one on each side of the conidiophore with each cell narrowly ellipsoid. Conidiogenous cells not observed. Conidia hyaline, smooth, clavate, aseptate, with a short appendage at the base, (18.5-)20.5-24.5(-26.2) $\times$ 
1.4-2.6 $\mu \mathrm{m}(\overline{\mathrm{x}}=22.9 \times 2.0 \mu \mathrm{m}, \mathrm{n}=45)$. Sexual morph: Undetermined.

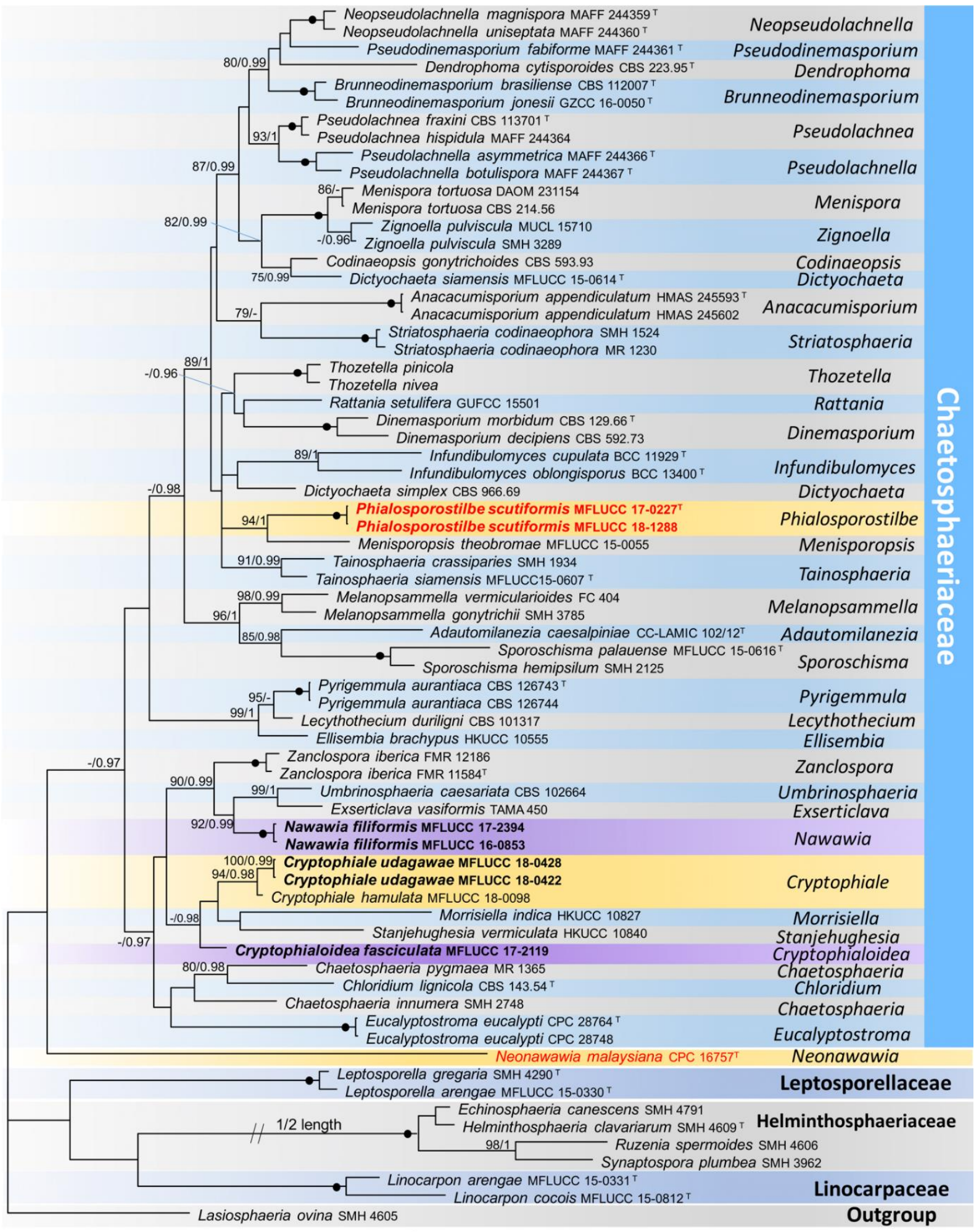

0.08

Figure 1 - Consensus phylogram (50\%) majority rule resulting from a Bayesian analysis of a combined LSU and ITS sequence alignment of Chaetosphaeriales. ML bootstrap proportion greater than $75 \%$ and Bayesian posterior probabilities above 0.95 are indicated above the nodes as BP/PP. The scale bar represents the expected number of changes per site. The tree is rooted with Lasiosphaeria ovina (SMH 4605). The strain numbers are noted after the species names with ex-type strains indicated with ${ }^{\mathrm{T}}$. The new collections are in bold with the new taxa in red. Branches with $100 \%$ ML BP and 1.0 PP are shown as black nodes. 

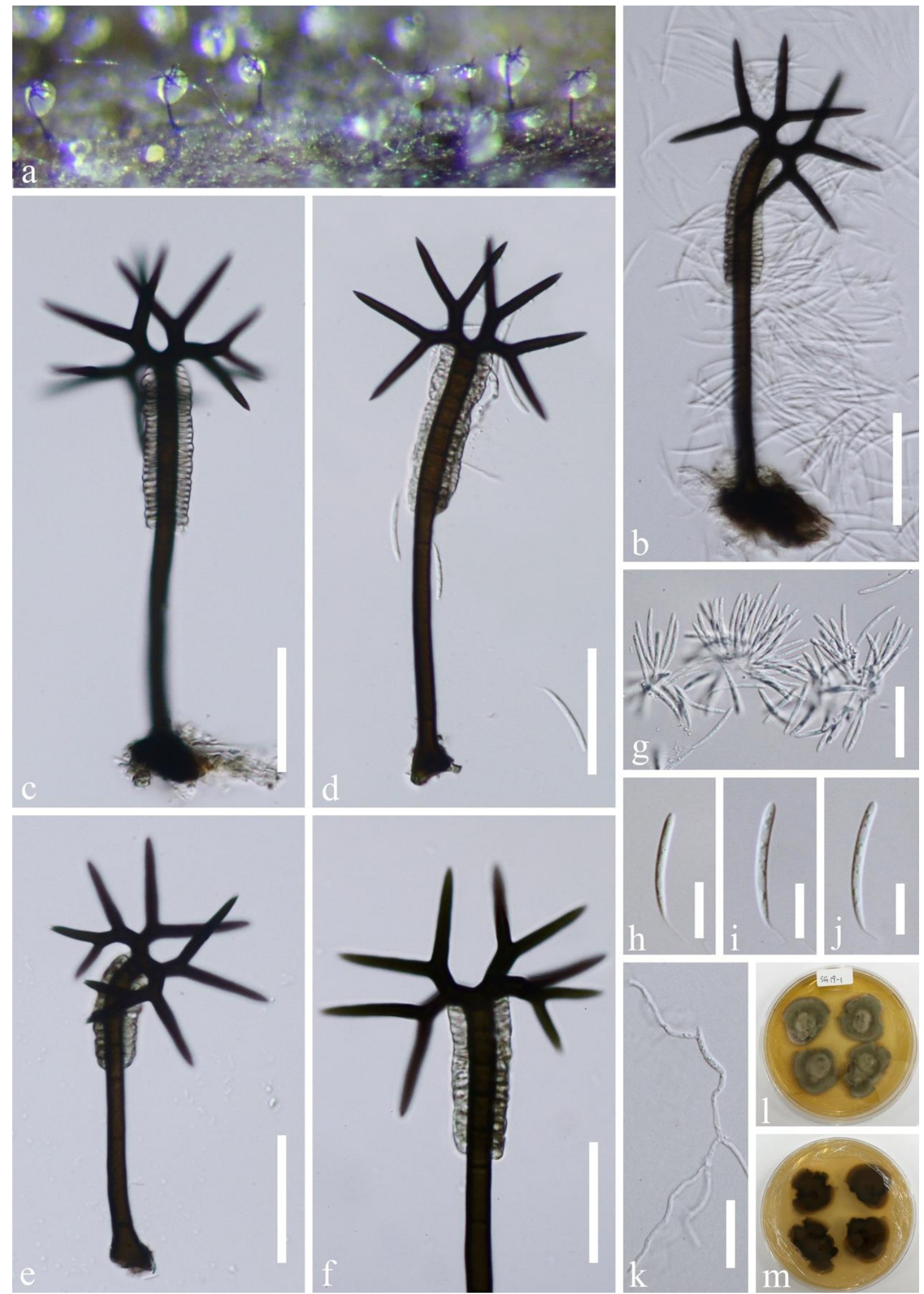

Figure 2 - Cryptophiale udagawae (MFLU 18-1497 reference specimen) a Colonies on woody substrate. $b-e$ Conidiophores with conidiogenous region. $f$ Conidiogenous region. $g-j$ Conidia. $\mathrm{k}$ Germinated conidium. 1, m Culture, 1 from above, $\mathrm{m}$ reverse. Scale bars: $\mathrm{b}-\mathrm{e}=40 \mu \mathrm{m}, \mathrm{f}, \mathrm{g}, \mathrm{k}=30$ $\mu \mathrm{m}, \mathrm{h}-\mathrm{j}=10 \mu \mathrm{m}$.

Cultural characteristics - Conidia germinating on PDA within $24 \mathrm{~h}$ and germ tubes produced from the base and the upper part. Colonies on MEA medium, reaching 5-10 mm diam. in a week at 
$25^{\circ} \mathrm{C}$, in natural light, circular, with fluffy, dense, brown mycelium on the surface; in reverse dark brown.

Material examined - CHINA, Guizhou Province, Dushan District, 25⒌ $57.9^{\prime} \mathrm{N}, 107^{\circ} 39^{\prime} \mathrm{E}$, on decaying wood submerged in a freshwater stream, 26 August 2017, J Yang, SG 19-1 (MFLU 18-1497 reference specimen designated here, HKAS 102153), living culture MFLUCC 18-0422, additional sequence of SSU: MH758205; ibid SG 41-1 (MFLU 18-1498), living culture MFLUCC 18-0428, additional sequence of SSU: MH758204.

Notes - Pirozynski (1968) established the genus Cryptophiale with the type species $C$. kakombensis Pirozynski and the second species C. udagawae. The genus is characterized by setiform, unbranched or apically dichotomous or verticillate conidiophores with a subapical or apical fertile region, monophialidic, obscured conidiogenous cells in two rows shielded by a plate of modified cells and hyaline, unicellular to multiseptate conidia produced in slimy masses on one side of the conidiophore (Pirozynski 1968, Seifert et al. 2011). Presently, 22 epithets are listed under the genus Cryptophiale in Index Fungorum (October 2018). Cryptophiale secunda Kuthubutheen \& B. Sutton and C. manifesta B. Sutton \& Hodges, however, have been transferred to the genus Cryptophialoidea (Kuthubutheen \& Nawawi 1987, 1994b). Thus, 20 species are accepted in Cryptophiale (Goh \& Hyde 1996, Whitton et al. 2012). Cryptophiale is morphologically similar to Cryptophialoidea and Paracryptophiale. Cryptophialoidea was separated from Cryptophiale in having obvious monophialidic conidiogenous cells arranged only on one side of the conidiophore and not covered by a shield of sterile cells (Kuthubutheen \& Nawawi 1987, Whitton et al. 2012). Paracryptophiale resembles Cryptophiale in having setiform conidiophores and typical cryptophiale-like conidiogenous cells aggregated into a fertile region with shield cells. The major difference separating the two genera is the multicellular, dictyosporous conidia produced by Paracryptophiale (Kuthubutheen \& Nawawi 1994a). Generic keys or synopses to Cryptophiale, Cryptophialoidea and Paracryptophiale were provided by Goh \& Hyde (1996), Delgado et al. (2005), Marques et al. (2008) and Whitton et al. (2012). In a study of microfungi associated with palms, Hyde et al. (1999) reported the connection of Cryptophiale udagawae and C. kakombensis with their sexual morphs Chaetosphaeria hongkongensis K.D. Hyde, Goh, J.E. Taylor \& J. Fröhl. and Chaetosphaeria saltuensis K.D. Hyde, Goh, J.E. Taylor \& J. Fröhl., respectively on host substrate. Hyde et al. (2018) provided the first sequence data for the genus Cryptophiale and showed its placement within the family Chaetosphaeriaceae.

In this study, phylogenetic analyses of combined LSU and ITS sequence data showed that Cryptophiale is related to Cryptophialoidea, Morrisiella and Stanjehughesia. Cryptophiale udagawae is a sister taxon to C. hamulata Whitton, K.D. Hyde \& McKenzie. Specimens observed in this study agree with the original diagnosis given in Pirozynski (1968). The conidiogenous regions of our collections $(37-63 \times 11-16 \mu \mathrm{m})$ are smaller than that in the holotype $(70-100 \times 15-27 \mu \mathrm{m})$, but similar in size to the later collections by Kuthubutheen \& Sutton (1985) and Marques et al. (2008). Unfortunately, the inconspicuous phialidic conidiogenous cells were not observed in our collections. We therefore provide the first sequence data for Cryptophiale udagawae and designate a reference specimen for the species (sensu Ariyawansa et al. 2014).

Cryptophialoidea fasciculata Kuthubutheen \& Nawawi, Mycol. Res. 98(6): 686 (1994) Fig. 3 Index Fungorum number: IF362165; Facesoffungi number: FoF04867

Saprobic on decaying plant substrates. Asexual morph: Colonies effuse, hairy, scattered, dark brown to black, glistening, with slimy mass of conidia on one side of the conidiophores. Mycelium mostly immersed, composed of smooth, septate, branched, pale brown to mid brown hyphae. Conidiophores macronematous, mononematous, erect, solitary, straight or flexuous, thick-walled, smooth, septate, subulate, dark brown, 185-236 $\times 4.8-6.2 \mu \mathrm{m}$. Conidiogenous region about halfway up and restricted only to the middle third of the conidiophore, comprising a row of phialides that are mostly closely arranged in discrete bundles and that all open on only one side of the conidiophore, 56-70 × 10.5-12.5 $\mu \mathrm{m}$. Conidiogenous cells monophialidic, intercalary, determinate, lageniform, extruded through minute pores on only one side of the conidiophores, light olivaceous brown, 7.2 
$11.2 \times 3.0-4.8 \mu \mathrm{m}(\overline{\mathrm{x}}=9.5 \times 3.8 \mu \mathrm{m}, \mathrm{n}=20)$. Conidia hyaline, smooth-walled, $0-1$-euseptate, falcate, with the base slightly narrower than the apex, sometimes guttulate, $26.5-33.4 \times 1.2-2.4 \mu \mathrm{m}(\overline{\mathrm{x}}=29.7$ $\times 1.7 \mu \mathrm{m}, \mathrm{n}=60$ ). Sexual morph: Undetermined.
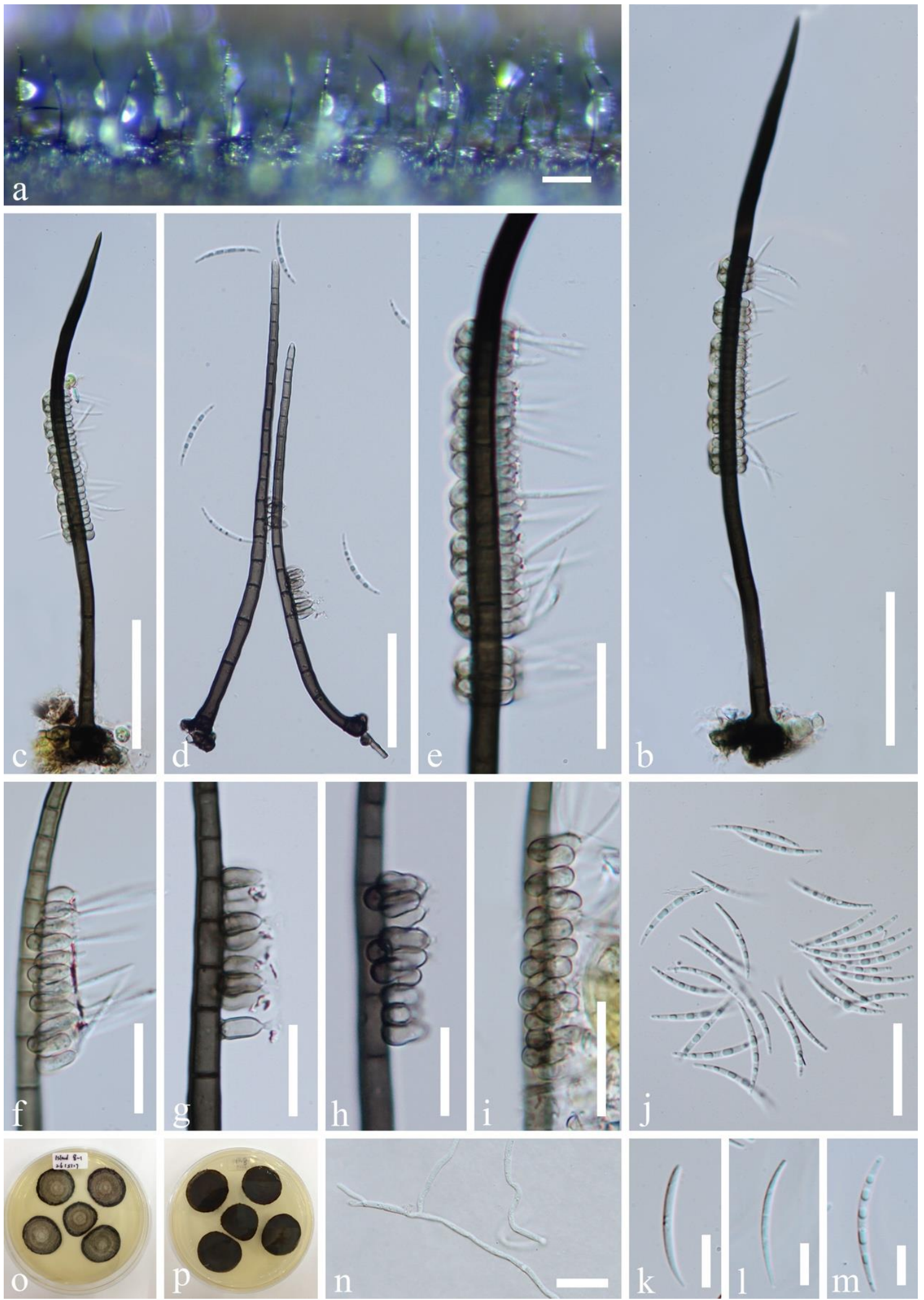

Figure 3 - Cryptophialoidea fasciculata (MFLU 18-1499 reference specimen). a Colonies on woody substrate. b, c Conidiophores with conidiogenous cells and conidia. d Conidiophores. $\mathrm{e}-\mathrm{i}$ Conidiogenous cells. $\mathrm{j}-\mathrm{m}$ Conidia. $\mathrm{n}$ Germinated conidium. $\mathrm{o}, \mathrm{p}$ Culture, $\mathrm{o}$ from above, $\mathrm{p}$ reverse. Scale bars: $\mathrm{a}=100 \mu \mathrm{m}, \mathrm{b}-\mathrm{d}=50 \mu \mathrm{m}, \mathrm{e}-\mathrm{i}, \mathrm{n}=20 \mu \mathrm{m}, \mathrm{j}=30 \mu \mathrm{m}, \mathrm{k}-\mathrm{m}=10 \mu \mathrm{m}$. 
Cultural characteristics - Conidia germinating on PDA within $24 \mathrm{~h}$ and germ tubes produced from the base and the upper part. Colonies on MEA medium, reaching 5-10 mm diam. in a week at $25^{\circ} \mathrm{C}$, in natural light, circular, with fluffy, dense, brown mycelium in the middle and sparse mycelium in the narrow outer ring on the surface with entire margin; in reverse dark brown.

Material examined - THAILAND, Trat Province, Amphoe Ko Chang, $12^{\circ} 08^{\prime} \mathrm{N}, 102^{\circ} 38^{\prime} \mathrm{E}$, on decaying wood submerged in a freshwater stream, 27 April 2017, YZ Lu, YJT 8-1 (MFLU 18-1499 reference specimen designated here), living culture MFLUCC 17-2119, SSU sequence: MH758202; ibid YJT 29-1 (HKAS 102154), living culture MFLUCC 17-2131 (sequence unavailable).

Notes - The generic concept of the genus Cryptophiale was restricted in Kirk \& Sutton (1985) to those fungi with sessile conidiogenous cells borne unilaterally and submedianly on a setiform conidiophore and obscured by a shield of sterile cells. However, Cryptophiale secunda is characterized by a single row of conspicuous phialides closely arranged on only one side of the conidiophore and located about halfway up the conidiophore without a protected shield of sterile cells (Kuthubutheen \& Sutton 1985, Kuthubutheen \& Nawawi 1987). Thus, Kuthubutheen \& Nawawi (1987) proposed the segregation of Cryptophiale secunda in a new genus Cryptophialoidea. Based on the generic limitation, Cryptophiale manifesta was also transferred to Cryptophialoidea with polyphialidic conidiogenous cells, which are distinct from the monophialidic conidiogenous cells of other species in Cryptophialoidea (Kuthubutheen \& Nawawi 1994b). Presently, five species are accepted in Cryptophialoidea (Index Fungorum 2018).

Cryptophialoidea fasciculata was re-collected in this study with the first sequence data for the genus. Our collection of Cryptophialoidea fasciculata is well-matched with the morphological characters in the original diagnosis of the holotype (Kuthubutheen \& Nawawi 1994b), except the conidiogenous cells in our collection $(7.2-11.2 \times 3-4.8 \mu \mathrm{m})$ are smaller than that in the holotype (12$18 \times 4-6 \mu \mathrm{m})$ and conidia in our collection $(26.5-33.4 \times 1.2-2.4 \mu \mathrm{m})$ are slightly larger than that in the holotype $(22-29 \times 1.5-2 \mu \mathrm{m})$. Cryptophialoidea fasciculata is unique by its discrete bundle-like conidiogenous cells. Due to the close phylogenetic relationship between Cryptophiale and Cryptophialoidea, molecular data of more taxa are required to confirm the separation of the two genera. In this study, sequence data is provided for Cryptophialoidea fasciculata and a reference specimen is designated for the species (sensu Ariyawansa et al. 2014).

Nawawia filiformis (Nawawi) Marvanová, Trans. Br. mycol. Soc. 75 (2): 227 (1980)

Fig. 4 Index Fungorum number: IF113008; Facesoffungi number: FoF04868

三 Clavatospora filiformis Nawawi, Trans. Br. mycol. Soc. 61(2): 390 (1973)

Saprobic on decaying plant substrates. Asexual morph: Colonies on the natural substratum effuse, hairy, scattered, dark brown, with glistening mass of conidia at the apex of conidiophores. Mycelium partly immersed, partly superficial, composed of pale brown, septate hyphae. Conidiophores macronematous, mononematous, single or in small groups, erect, straight, rarely geniculate, smooth, mid or dark brown, becoming paler towards the apex, septate, (49-)77-215($236) \times 4.1-5.9 \mu \mathrm{m}$. Conidiogenous cells integrated, terminal, monophialidic, pale brown, smooth, cylindrical or lageniform, often with up to three percurrent proliferations. Conidia hyaline, roundtetrahedral, pentahedral or pyramidal, aseptate, smooth, thin-walled, guttulate, viewed from above triangular or quadrangular, 8.5-16.2 $\mu \mathrm{m}(\overline{\mathrm{x}}=12.3 \mu \mathrm{m}, \mathrm{n}=35)$ long of the side, with an obconical truncate base, with an appendage at the apex of each corner. Sexual morph: Undetermined.

Cultural characteristics - Conidia germinating on PDA within $24 \mathrm{~h}$ and germ tubes produced from the base. Colonies on MEA medium slow-growing, reaching 5-10 $\mathrm{mm}$ diam. in a month at $25^{\circ} \mathrm{C}$, in natural light, circular, with fluffy, dense, brown mycelium on the surface with entire margin; in reverse dark brown.

Material examined - THAILAND, Trat Province, Amphoe Ko Chang, $12^{\circ} 08^{\prime} \mathrm{N}, 102^{\circ} 38^{\prime} \mathrm{E}$, on decaying wood submerged in a freshwater stream, 27 April 2017, YZ Lu, YJT 23-2 (MFLU 18-1500 reference specimen designated here, HKAS 102155), living culture MFLUCC 17-2394, additional sequence of SSU: MH758203; THAILAND, Krabi Province, on decaying wood submerged in a freshwater stream near Morakot Lake, 15 December 2015, S. Tibpromma, Site 6-6-4 (MFLU 18- 
1501), living culture MFLUCC 16-0853, additional sequence of SSU: MH758200.
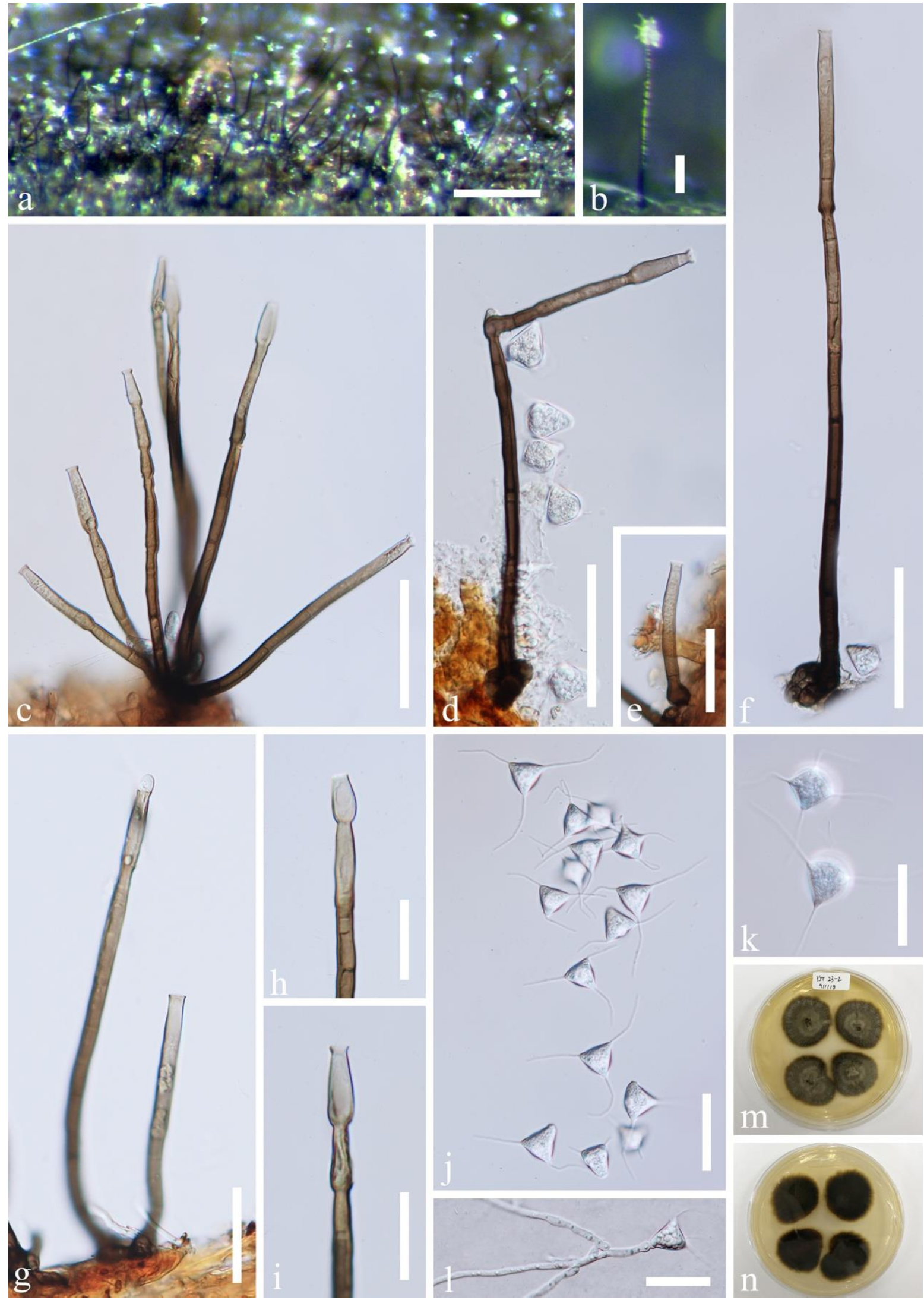

Figure 4 - Nawawia filiformis (MFLU 18-1500 reference specimen). a Colonies on woody substrate. $\mathrm{b}$ Conidiophore with mass of conidia on woody substrate. $\mathrm{c}-\mathrm{f}$ Conidiophores. $\mathrm{g}$ Conidial formation. $\mathrm{h}$, i Conidiogenous cells. $\mathrm{j}$, $\mathrm{k}$ Conidia. 1 Germinated conidium. $\mathrm{m}, \mathrm{n}$ Culture, $\mathrm{m}$ from above, $\mathrm{n}$ reverse. Scale bars: $\mathrm{a}=200 \mu \mathrm{m}, \mathrm{b}-\mathrm{d}, \mathrm{f}=50 \mu \mathrm{m}, \mathrm{e}, \mathrm{g}, \mathrm{j}-\mathrm{l}=30 \mu \mathrm{m}, \mathrm{h}, \mathrm{i}=20 \mu \mathrm{m}$. 
Notes - The genus Nawawia was established by Marvanová (1980) with N. filiformis (as Clavatospora filiformis) transferred from Clavatospora. Nawawia is characterized by having brown, macronematous conidiophores, monophialidic conidiogenous cells sometimes with percurrent proliferations and hyaline, turbinate-tetrahedral to obpyramidal conidia with the blunt corners at the distal end each provided with a distinct hair-like appendage. Goh et al. (2014) provided a synopsis for the genus with six known species: $N$. dendroidea K.D. Hyde, Goh \& Steinke, N. filiformis, $N$. malaysiana Crous \& S.S. Lee, N. nitida Kuthub., G.M. Liew \& Nawawi, N. quadrisetulata Goh, W.Y. Lau \& K.C. Teo and N. sasae-kurilensis Melnik \& K.D. Hyde. Subsequently, Peng et al. (2016) introduced the seventh species $N$. oviformis J. Peng \& Z.F. Yu. Among the seven species, five are reported from aquatic habitats on submerged wood or leaves, with $N$. malaysiana and N. sasaekurilensis found in terrestrial habitats (Nawawi 1973, Kuthubutheen et al. 1992, Hyde et al. 1996, Mel'nik \& Hyde 2006, Crous et al. 2009, Goh et al. 2014, Peng et al. 2016). Sequence data is only available for $N$. malaysiana which is the only coelomycetous species within the genus. However, Crous et al. (2009) provided the BLAST results of the LSU sequence of $N$. malaysiana without carrying out a phylogenetic analysis. Nawawia dendroidea already provided the difference from other species in the genus in having synnematous conidiophores, which match the generic concept of Phialosporostilbe. The type species Nawawia filiformis has been reported worldwide (Nawawi 1973, Wu \& McKenzie 2003, Pinnoi et al. 2006, Raja et al. 2009, Sudheep \& Sridhar 2011), and it is the only species in the genus which produced a Chloridium synanamorph (conidia ellipsoid, without appendage) based on cultural studies (Nawawi 1973, Wu \& McKenzie 2003).

Morphological characters of our collection agree with the original diagnosis and previous reports of Nawawia filiformis. Nawawia filiformis morphologically resembles N. quadrisetulata in having brown, mononematous conidiophores, monophialidic conidiogenous cells with a collarette and hyaline turbinate-tetrahedral to obpyramidal conidia. However, conidia of $N$. filiformis have $3-$ 4 (mostly 3 ) appendages while those in $N$. quadrisetulata have 4-5 (mostly 4) appendages. The first sequence data of the species is generated in this study. Phylogenetic analyses showed that two isolates of $N$. filiformis clustered together and they are close to the genera Exserticlava, Umbrinosphaeria and Zanclospora. In this study, sequence data is provided for Nawawia filiformis and a reference specimen is designated for the species (sensu Ariyawansa et al. 2014).

Neonawawia J. Yang, K.D. Hyde \& J.K. Liu, gen. nov.

Index Fungorum number: IF555449; Facesoffungi number: FoF05180

Etymology - Referring to the conidial similarity to the genus Nawawia.

Conidiomata sporodochial, semicupulate. Mycelium consisting of pale brown, smooth to somewhat roughened, septate, branched hyphae. Conidiophores hyaline to pale brown, smooth, subcylindrical, aggregated, branched, rarely loose or solitary, septate, or reduced to clavate cells giving rise to 7-8 conidiogenous cells radiating from the apex. Conidiogenous cells terminal, monophialidic, hyaline to pale brown, smooth, subcylindrical to somewhat ampulliform, tapering towards the apex. Conidia in olivaceous, slimy masses, solitary, hyaline, smooth, lobed, with 4-6 projections, aseptate, with a hair-like appendage at each corner, truncate at the base.

Type species - Neonawawia malaysiana.

Neonawawia malaysiana (Crous \& S.S. Lee) J. Yang, K.D. Hyde \& J.K. Liu, comb. nov.

Index Fungorum number: IF 555450; Facesoffungi number: FoF05181

三Nawawia malaysiana Crous \& S.S. Lee, Persoonia 23: 1952009

Holotype - MALAYSIA, Sarawak, on leaves of Eucalyptus urophylla, 20 April 2009, S.S. Lee, CBS H-20345, ex-type living cultures CPC 16757 = CBS 125544, CPC 16758.

Notes - The BLAST results of the LSU sequence showed that Nawawia malaysiana was close to several Chaetosphaeria species (Crous et al. 2009). It has similar conidial ontogeny and conidial morphology to Nawawia, and this taxon was accommodated in the genus while no other molecular data were available. Goh et al. (2014) questioned the taxonomic placement of $N$. malaysiana in the genus as the species differs from the other six species in being sporodochial, producing conidia that 
are distinctly smaller and fusoid to ellipsoid in side-view, and it was isolated from the apex of a conidiomatal spore mass of a foliicolous Satchmopsis species. It is likely that N. malaysiana was misclassified based on the phylogenetic results and it should not belong to the genus. In this study, phylogenetic analyses indicated that the type species $N$. filiformis grouped together with the genera Exserticlava, Umbrinosphaeria and Zanclospora. Nawawia malaysiana, however, formed a sister clade to the family Chaetosphaeriaceae. We therefore introduce a new genus Neonawawia to accommodate this taxon and treat it as genera incertae sedis in the order Chaetosphaeriales.

Phialosporostilbe scutiformis N.G. Liu, J. Yang \& K.D. Hyde, sp. nov.

Figs 5-6

Index Fungorum number: IF555325; Facesoffungi number: FoF04869

Etymology - Referring to the shield-shaped conidia from front view.

Saprobic on decaying plant substrates. Asexual morph: Colonies effuse, scattered, dark brown, with masses of conidia on the apex of conidiophores. Mycelium partly immersed, partly superficial. Setae simple, central, solitary, erect, dark brown or dark olivaceous, paler at the apex, rarely fertilizable, lower part encased by the compacted conidiophores, $(250-) 380-500(-540) \times 4.2-5.2 \mu \mathrm{m}$ $(\overline{\mathrm{x}}=435 \times 4.8 \mu \mathrm{m}, \mathrm{n}=15)$, wider than each conidiophore. Conidiophores macronematous, synnematous, erect, solitary, septate, smooth, dark brown or dark olivaceous, becoming paler towards the apex, cylindrical, slightly tapering at the apical part, $(175-) 245-415(-460) \times 3.3-4.8 \mu \mathrm{m}(\overline{\mathrm{x}}=$ $330 \times 4 \mu \mathrm{m}, \mathrm{n}=20)$ of the single conidiophore, $14-22(-30) \mu \mathrm{m}(\overline{\mathrm{x}}=18.5 \mu \mathrm{m}, \mathrm{n}=15)$ wide of the synnemata, often splaying out along the sides of the upper half of the synnemata, slightly undulated at the splayed part. Conidiogenous cells monophialidic, terminal, integrated, diverging from the main axis of the synnema, pale brown, subhyaline towards the apex, cylindrical to cylindric-clavate, 35$45 \mu \mathrm{m}$ long, 3.5-4.7 $\mu \mathrm{m}$ wide at the base, 1.9-3.0 $\mu \mathrm{m}$ wide at the tip, with an inconspicuous apical collarette. Conidia round-tetrahedral, pyramidal, smooth, aseptate, thin-walled, guttulate, viewed from above triangular, (5.5-)6-8.2(-8.7) $\mu \mathrm{m}(\overline{\mathrm{x}}=7.0 \mu \mathrm{m}, \mathrm{n}=45)$ long of each above edge, 7.5-11.6 $\mu \mathrm{m}(\overline{\mathrm{x}}=9.5 \mu \mathrm{m}, \mathrm{n}=40)$ long of the side, with an appendage $3.5-7.5 \mu \mathrm{m}(\overline{\mathrm{x}}=5.6 \mu \mathrm{m}, \mathrm{n}=40)$ long at each corner. Sexual morph: Undetermined.

Cultural characteristics - Conidia germinating on PDA within $24 \mathrm{~h}$ and germ tubes produced from the base. Colonies on MEA medium, reaching 5-10 mm diam. in a week at $25^{\circ} \mathrm{C}$, in natural light, circular, with dense, yellowish-brown mycelium in the middle and yellow mycelium in the outer ring on the surface with undulate margin; in reverse mid brown.

Material examined - CHINA, Guizhou Province, Anshun city, Gaodang village, $26^{\circ} 4.2^{\prime} \mathrm{N}$, $105^{\circ} 41.8^{\prime} \mathrm{E}$, on decaying wood submerged in Suoluo river, 19 October 2016, J Yang, GD 12-6 (MFLU 18-1502 holotype, HKAS 102156 isotype); ex-type living cultures MFLUCC 17-0227, GZCC 170043, additional sequence of SSU: MH758201; THIALAND, Chiang Rai Province, on decaying wood submerged in a stream, 16 June 2017, NG Liu, CR004-1 (HKAS 102205 paratype), living culture MFLUCC 18-1288.

Notes - The genus Phialosporostilbe was introduced by Sierra \& Portales (1985) based on the type species $P$. turbinata Mercado \& J. Mena. It is characterized by synnematous conidiophores, monophialidic conidiogenous cells and subhyaline, turbinate or cordiform conidia with each bearing three apical setulae (Sierra \& Portales 1985). Subsequently, another four species have been included in the genus, namely $P$. catenata Sureshkumar, Sharath, Kunwar \& Manohar., P. gregariclava Shirouzu \& Y. Harada, P. setosa Bhat \& W.B. Kendr., and P. yadongensis Y.M. Wu \& T.Y. Zhang from different habitats and countries (Bhat \& Kendrick 1993, Shirouzu \& Harada 2004, Sureshkumar et al. 2005, Wu \& Zhang 2009). The genus Phialosporostilbe resembles Nawawia in having macronematous conidiophores, monophialidic conidiogenous cells and hyaline conidia similar in shape. However, Nawawia has mononematous conidiophores, while Phialosporostilbe is characterized by synnematous conidiophores. The two genera have ever been considered to be congeneric (Bhat \& Kendrick 1993, Hyde et al. 1996, Shirouzu \& Harada 2004) due to the similar conidial ontogeny and conidial morphology.

The first sequence data for the genus is generated for Phialosporostilbe scutiformis in this study. Phylogenetic analyses indicated that $P$. scutiformis clustered as a sister clade to Menisporopsis 
theobromae S. Hughes with good support. The two strains of P. scutiformis (MFLUCC 17-0227 and MFLUCC 18-1288), isolated from specimens material collected in China and Thailand respectively, are regarded as the same species based on the molecular data. It is shown that Phialosporostilbe and Nawawia are phylogenetically distinct genera.
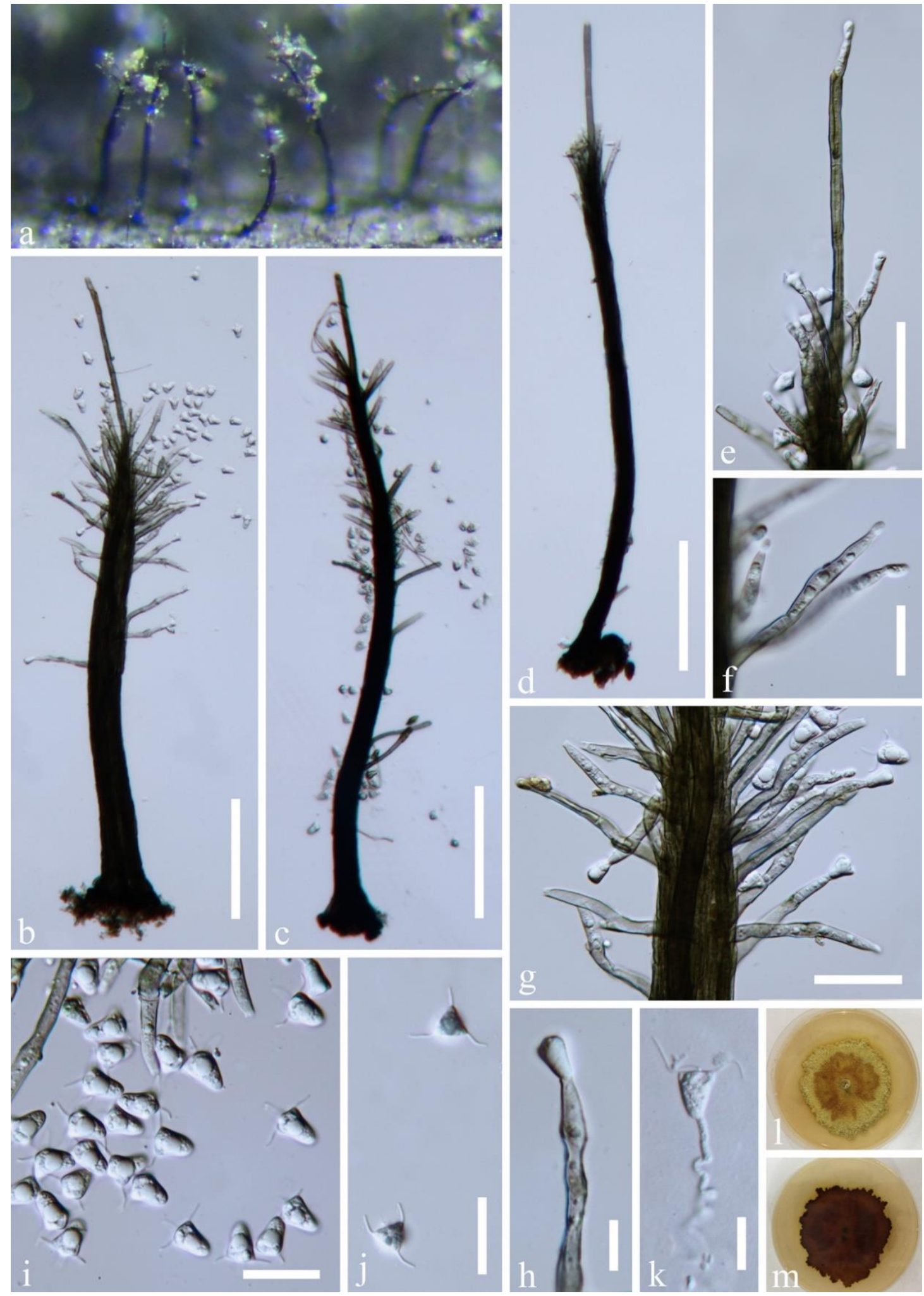

Figure 5 - Phialosporostilbe scutiformis (MFLU 18-1502 holotype, collected from China). a Colonies on woody substrate. b-d Conidiophores. e- $\mathrm{h}$ Conidiogenous cells with conidia. $\mathrm{i}, \mathrm{j}$ Conidia. $\mathrm{k}$ Germinated conidium. $1, \mathrm{~m}$ Culture, 1 from above, $\mathrm{m}$ reverse. Scale bars: $\mathrm{b}-\mathrm{d}=100$ $\mu \mathrm{m}, \mathrm{e}=50 \mu \mathrm{m}, \mathrm{f}, \mathrm{i}, \mathrm{j}=20 \mu \mathrm{m}, \mathrm{g}=30 \mu \mathrm{m}, \mathrm{h}, \mathrm{k}=10 \mu \mathrm{m}$. 

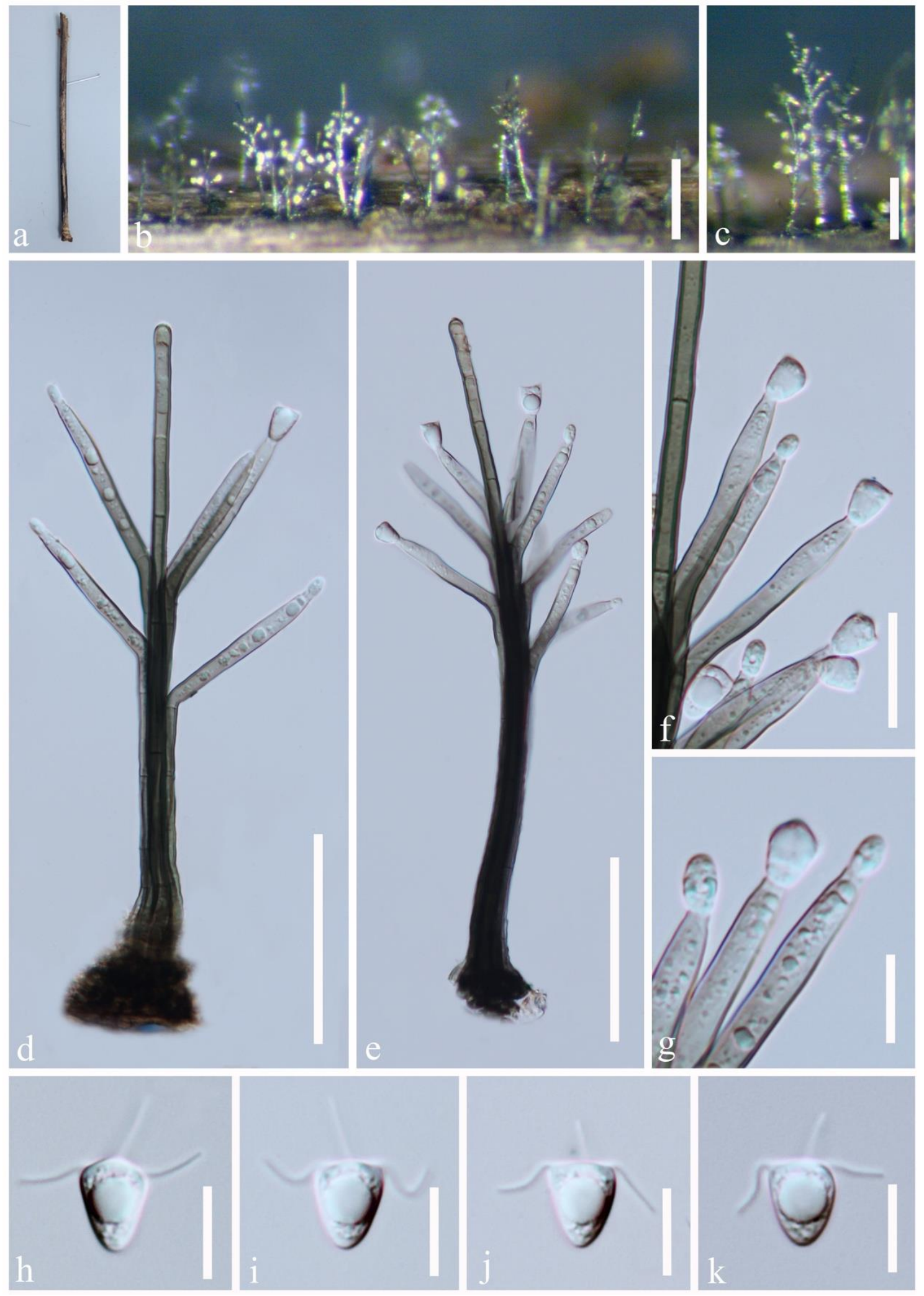

Figure 6 - Phialosporostilbe scutiformis (HKAS 102205 paratype, collected from Thailand). a Specimen. $\mathrm{b}-\mathrm{c}$ Colonies on substrate. $\mathrm{d}-\mathrm{e}$ Fruiting bodies. $\mathrm{f}-\mathrm{g}$ Conidiogenous cells and Conidia. $\mathrm{h}-\mathrm{k}$ Conidia. Scale bar: $\mathrm{b}=200 \mu \mathrm{m}, \mathrm{c}=100 \mu \mathrm{m}, \mathrm{d}-\mathrm{e}=50 \mu \mathrm{m}, \mathrm{f}=20 \mu \mathrm{m}, \mathrm{g}-\mathrm{k}=10 \mu \mathrm{m}$.

Phialosporostilbe scutiformis is morphologically similar to P. turbinata and Nawawia (Phialosporostilbe) dendroidea in having tree-like structures of conidiophores and similar conidial shape and size. However, $P$. scutiformis is distinguished from the two species by its conspicuous seta 
which is erect in the center of the lower conidiophores. Phialosporostilbe scutiformis resembles Menisporopsis theobromae in having synnematous conidiophores with a conspicuous central seta, terminal, monophialidic conidiogenous cells producing hyaline, aseptate conidia with appendages. However, conidiophores of $M$. theobromae are closely compacted towards the apex and halfway up the seta, while in P. scutiformis they are 1/4 or 1/5 lower on the seta and splay out at the upper part to form the tree-like shape. Moreover, M. theobromae produces clavate to cylindrical conidia which are slightly curved with hyaline appendages at both ends, but P. scutiformis has round-tetrahedral, pyramidal conidia bearing three appendages with one at each corner.

Phialosporostilbe dendroidea (K.D. Hyde, Goh \& T. Steinke) J. Yang \& K.D. Hyde, comb. nov. Index Fungorum number: IF555326; Facesoffungi number: FoF04870

$\equiv$ Nawawia dendroidea K.D. Hyde, Goh \& T. Steinke, Mycol. Res. 100(7): 810 (1996).

Holotype - South Africa, Durban, Palmiet River, on submerged pieces of stems of Phragmites, Nov. 1994, K. D. Hyde \& T. Steinke, KDH 2157, BRIP 22870.

Notes - Nawawia dendroidea was introduced within Nawawia due to the consideration that Phialosporostilbe is congeneric with Nawawia, then the name Nawawia has priority over Phialosporostilbe (Hyde et al. 1996). Phylogenetic studies have indicated that Nawawia and Phialosporostilbe are phylogenetically distinct. Nawawia dendroidea differs from other Nawawia species in having synnematous conidiophores, which match the generic concept of Phialosporostilbe. To be in line with the phylogenetic result and generic concept, we therefore transfer $N$. dendroidea to the genus Phialosporostilbe.

\section{Acknowledgement}

We would like to thank The Research of Featured Microbial Resources and Diversity Investigation in the Southwest Karst area (project no. 2014FY120100) for its financial support. Kevin D. Hyde would like to thank the Thailand Research grants entitled "The future of specialist fungi in a changing climate: baseline data for generalist and specialist fungi associated with ants, Rhododendron species and Dracaena species" (grant no: DBG6080013) and "Impact of climate change on fungal diversity and biogeography in the Greater Mekong Subregion" (grant no: RDG6130001) for supporting this study. Jing Yang thanks Shaun Pennycook for the corrections to the Latin names.

\section{References}

Ariyawansa HA, Hawksworth DL, Hyde KD, Jones EBG et al. 2014 - Epitypification and neotypification: guidelines with appropriate and inappropriate examples. Fungal Diversity 69, 57-91.

Bhat DJ, Kendrick B. 1993 - Twenty-five new conidial fungi from the Western Ghats and the Andaman Islands (India). Mycotaxon 49, 19-90.

Chomnunti P, Hongsanan S, Hudson BA, Tian Q et al. 2014 - The sooty moulds. Fungal Diversity $66,1-36$.

Crous PW, Groenewald JZ, Lee SS. 2009 - Fungal Planet 41 - Nawawia malaysiana. Persoonia 23, 194-195.

Crous PW, Verkley GJ, Christensen M, Castañeda-Ruiz RF, Groenewald JZ. 2012 - How important are conidial appendages? Persoonia 28, 126-137.

Crous PW, Wingfield MJ, Burgess TI, Hardy GEStJ et al. 2016 - Fungal Planet description sheets: 469-557. Persoonia 37, 218-403.

Delgado G, Mena-Portales J, Gené J, Guarro J. 2005 - New species of Cryptophialoidea and Hughesinia (hyphomycetes, anamorphic fungi) from Cuba. Fungal Diversity 20, 31-38.

Goh TK, Hyde KD. 1996 - Cryptophiale multiseptata, sp. nov. from submerged wood in Australia, and keys to the genus. Mycological Research 100, 999-1004.

Goh TK, Lau WY, Teo KC. 2014 - A new species of Nawawia from Malaysia, with a synopsis of the 
genus. Mycotaxon 129, 109-118.

Hashimoto A, Sato G, Matsuda T, Hirayama K et al. 2015a - Molecular taxonomy of Dinemasporium and its allied genera. Mycoscience 56, 86-101.

Hashimoto A, Sato G, Matsuda T, Matsumura M et al. 2015b - Taxonomic revision of Pseudolachnea and Pseudolachnella and establishment of Neopseudolachnella and Pseudodinemasporium gen. nov. Mycologia 107, 383-408.

Hyde KD, Chaiwan N, Norphanphoun C, Boonmee S et al. 2018 - Mycosphere notes 169-224. Mycosphere 9(2), 271-430.

Hyde KD, Goh TK, Steinke T. 1996 - Nawawia dendroidea, a new synnematous hyphomycete from submerged Phragmites in South Africa. Mycological Research 100, 810-814.

Hyde KD, Goh TK, Taylor JE. Frohlich J. 1999 - Byssosphaeria, Chaetosphaeria, Niesslia and Ornatispora gen. nov., from palms. Mycological Research 103, 1423-1439.

Index Fungorum. 2018 - http://www.indexfungorum.org

Jayasiri SC, Hyde KD, Ariyawansa HA, Bhat DJ et al. 2015 - The faces of fungi database: fungal names linked with morphology, phylogeny and human impacts. Fungal Diversity 74(1), 3-18.

Katoh K, Standley DM. 2013 - Multiple sequence alignment software version 7: improvements in performance and usability. Molecular Biology and Evolution 30, 772-780.

Kirk PM, Sutton BC. 1985 - A reassessment of the anamorph genus Chaetopsina (hyphomycetes). Transactions of the British Mycological Society 85, 709-718.

Konta S, Hongsanan S, Eungwanichayapant PD, Liu JK et al. 2017 - Leptosporella (Leptosporellaceae fam. nov.) and Linocarpon and Neolinocarpon (Linocarpaceae fam. nov.) are accommodated in Chaetosphaeriales. Mycosphere 8(10), 1943-1974.

Kuthubutheen AJ, Liew GM, Nawawi A. 1992 - Nawawia nitida sp. nov. (hyphomycetes) and further records of Nawawia filiformis from Malaysia. Canadian Journal of Botany 70, 96-100.

Kuthubutheen AJ, Nawawi A. 1987 - Cryptophialoidea gen. nov. on decaying leaves from Malaysia. Transactions of the British Mycological Society 89, 581-583.

Kuthubutheen AJ, Nawawi A. 1994a - Paracryptophiale kamaruddinii gen. nov. from submerged litter in Malaysia. Mycological Research 98, 125-126.

Kuthubutheen AJ, Nawawi A. 1994b - Cryptophialoidea fasciculata sp. nov. and C. manifesta comb. nov. from Malaysia. Mycological Research 98, 686-688.

Kuthubutheen AJ, Sutton BC. 1985 - Cryptophiale from Malaysia. Transactions of the British Mycological Society 84, 303-306.

Larget B, Simon DL. 1999 - Markov Chain Monte Carlo algorithms for the Bayesian analysis of phylogenetic trees. Molecular Biology and Evolution 16, 750-759.

Liu JK, Hyde KD, Jones EBG, Ariyawansa HA et al. 2015 - Fungal diversity notes 1-110: taxonomic and phylogenetic contributions to fungal species. Fungal Diversity 72, 1-197.

Liu JK, Yang J, Maharachchikumbura SSN, McKenzie EHC et al. 2016 - Novel chaetosphaeriaceous hyphomycetes from aquatic habitats. Mycological Progress 15, 1157- 1167.

Lumbsch HT, Huhndorf SM. 2010 - Outline of Ascomycota - 2009. Myconet 14, 1-64.

Ma YR, Xia JW, Gao JM, Li Z, Zhang XG. 2016 - Anacacumisporium, a new genus based on morphology and molecular analyses from Hainan, China. Cryptogamie Mycologie 37 (1), 4559.

Maharachchikumbura SSN, Hyde KD, Jones EBG, McKenzie EHC et al. 2016 - Families of Sordariomycetes. Fungal Diversity 79, 1-317.

Maharachchikumbura SSN, Hyde KD, Jones EG, McKenzie EHC et al. 2015 - Towards a natural classification and backbone tree for Sordariomycetes. Fungal Divers 72, 199-301.

Marques MFO, Da Cruz ACR, Barbosa FF, Gusmão LFP. 2008 - Cryptophiale and Cryptophialoidea (Conidial fungi) from Brazil and keys to the genera. Revista Brasileira de Botanica 31, 339344.

Marvanová L. 1980 - New or noteworthy aquatic hyphomycetes: Clavatospora, Heliscella, Nawawia and Heliscina. Transactions of the British Mycological Society 75, 221-231.

Mel'nik VA, Hyde KD. 2006 - Nawawia sasae-kurilenses sp. nov. from the Russian Far East. 
Mikologiya i Fitopatologiya 40, 411-414.

Miller MA, Pfeiffer W, Schwartz T. 2010 - Creating the CIPRES Science Gateway for inference of large phylogenetic trees. In: Proceedings of the Gateway Computing Environments Workshop (GCE), 14 Nov 2010. New Orleans, LA 1-8.

Nawawi A. 1973 - Clavatospora filiformis sp. nov., an aquatic hyphomycete from Malaysia. Transactions of the British Mycological Society 61, 390-393.

Nylander J. 2008 - MrModeltest2 v. 2.3 (Program for selecting DNA substitution models using PAUP*). Evolutionary Biology Centre, Uppsala, Sweden.

Peng J, Chang D, Huang Y, Yu ZF. 2016 - Nawawia oviformis sp. nov. from China. Mycotaxon 131, 735-738.

Pinnoi A, Lumyong S, Hyde KD, Jones EBG. 2006 - Biodiversity of fungi on the palm Eleiodoxa conferta in Sirindhorn peat swamp forest, Narathiwat, Thailand. Fungal Diversity 22, 205-218.

Pirozynski KA. 1968 - Cryptophiale, a new genus of Hyphomycetes. Canadian Journal of Botany 46(9), 1123-1127.

Raja HA, Schmit JP, Shearer CA. 2009 - Longitudinal, habitat, and substrate distribution patterns of freshwater ascomycetes in the Florida peninsula. Biodiversity and Conservation 18, 419-455.

Rannala B, Yang Z. 1996 - Probability distribution of molecular evolutionary trees: a new method of phylogenetic inference. Journal of Molecular Evolution 43, 304-311.

Réblová M, Barr ME, Samuels GJ. 1999 - Chaetosphaeriaceae, a new family for Chaetosphaeria and its relatives. Sydowia 51, 49-70.

Réblová M, Winka K. 2000 - Phylogeny of Chaetosphaeria and its anamorphs based on morphological and molecular data. Mycologia 22, 939-954.

Réblová M. 2000 - The genus Chaetosphaeria and its anamorphs. Studies in Mycology 45, 149-168.

Ronquist F, Huelsenbeck JP. 2003 - MrBayes 3: Bayesian phylogenetic inference under mixed models. Bioinformatics 19, 1572-1574.

Seifert KA, Morgan-Jones G, Gams W, Kendrick B. 2011 - The genera of hyphomycetes. Utrecht, The Netherlands, CBS-KNAW Fungal Biodiversity Centre.

Shirouzu T, Harada Y. 2004 - Bambusicolous fungi in Japan (2): Phialosporostilbe gregariclava, a new anamorphic fungus from Sasa. Mycoscience 45, 390-394.

Sierra ÁM, Portales JM. 1985 - Nuevo género de hifomicete fialídico de Cuba. Revista del Jardín Botánico Nacional 6 (3), 57-60.

Stamatakis A, Hoover P, Rougemont J. 2008 - A rapid bootstrap algorithm for the RAxML web servers. Syst Biol 57, 758-771.

Stamatakis A. 2006 - RAxML-VI-HPC: maximum likelihood-based phylogenetic analyses with thousands of taxa and mixed models. Bioinformatics 22, 2688-2690.

Sudheep NM, Sridhar KR. 2011 - Diversity of lignicolous and Ingoldian fungi on woody litter from the River Kali (Western Ghats, India), Mycology 2, 98-108.

Sureshkumar G, Sharath Babu K, Kunwar IK, Manoharachary C. 2005 - Two new hyphomycetous fungal species from India. Mycotaxon 92, 279-283.

Vilgalys R, Hester M. 1990 - Rapid genetic identification and mapping of enzymatically amplified ribosomal DNA from several Cryptococcus species. Journal of bacteriology 172(8), 4238-4246.

White TJ, Bruns T, Lee SJ, Taylor JW. 1990 - Amplification and direct sequencing of fungal ribosomal RNA genes for phylogenetics. PCR protocols: a guide to methods and applications $18(1), 315-322$.

Whitton SR, McKenzie EHC, Hyde KD. 2012 - Anamorphic Fungi Associated with Pandanaceae. In: Whitton SR, McKenzie EHC, Hyde KD (Eds.) Fungi Associated with Pandanaceae. Fungal Diversity Research Series 21, 1-457.

Wijayawardene NN, Hyde KD, Lumbsch HT, Liu JK et al. 2018 - Outline of Ascomycota: 2017. Fungal Diversity 88, 167-263.

Wu WP, McKenzie EHC. 2003 - Obeliospora minima sp. nov. and four other hyphomycetes with conidia bearing appendages. Fungal Diversity 12, 223-234.

Wu YM, Zhang TY. 2009 - New species of Phialosporostilbe and Pleurothecium from soil. 
Mycotaxon 110, 1-4.

Zhaxybayeva O, Gogarten JP. 2002 - Bootstrap, Bayesian probability and maximum likelihood mapping: exploring new tools for comparative genome analyses. BMC Genomics 3, 4. 